\author{
TADEUSZ KOCOWSKI \\ Uniwersytet Wrocławski \\ e-mail: tadeusz.kocowski@uwr.edu.pl
}

\title{
Gmina a Ochotnicze Straże Pożarne w wykonywaniu zadań w zakresie ochrony przeciwpożarowej
}

\section{Wstęp}

Jednym z zadań publicznych gminy są sprawy porządku publicznego i bezpieczeństwa obywateli oraz ochrony przeciwpożarowej i przeciwpowodziowej, w tym wyposażenia i utrzymania gminnego magazynu przeciwpowodziowego ${ }^{1}$. Działające na terenie gminy Ochotnicze Straże Pożarne to umundurowane jednostki, wyposażone w specjalistyczny sprzęt, przeznaczone w szczególności do walki z pożarami, klęskami żywiołowymi lub innymi miejscowymi zagrożenia$\mathrm{mi}^{2}$. Ochotnicze Straże Pożarne są stowarzyszeniami, czyli dobrowolnymi, samorządnymi, trwałymi zrzeszeniami o celach niezarobkowych, posiadającymi osobowość prawną, przy czym - co należy podkreślić — są także jednostkami organizacyjnymi ochrony przeciwpożarowej i $\mathrm{w}$ tym zakresie podlegają przepisom ustawy przeciwpożarowej.

Sfery działań gminy i Ochotniczych Straży Pożarnych we wskazanym powyżej zakresie niewątpliwie formalnie się pokrywają, w dodatku ich działania mają miejsce na tym samym terytorium. Trzeba więc rozważyć zagadnienie zakresu działania tych jednostek i wzajemnych relacji, jakie występują w związku z koniecznością realizacji tego samego celu. Mamy tu bowiem, z jednej strony, podstawową jednostkę samorządu terytorialnego, jaką jest gmina, $z$ drugiej zaś stowarzyszenie z osobowością prawną, gdyż właśnie taki status ma Ochotnicza

${ }^{1}$ Ustawa z dnia 8 marca 1990 r. o samorządzie gminnym (tekst jedn. Dz.U. z 2001 r. Nr 142, poz. 1591).

${ }^{2}$ Ustawa z dnia 24 sierpnia 1991 r. o ochronie przeciwpożarowej (Dz.U z 2017 r. poz. 736). 
Straż Pożarna. Istotne wydają się zatem relacje zachodzące między tymi podmiotami podczas realizacji zadań mających na celu zapewnienie bezpieczeństwa i ochrony przeciwpożarowej. Stąd konieczność analizy obowiązującego prawodawstwa w tej dziedzinie.

\section{Istota gminy}

Gmina, zgodnie z art. 164 Konstytucji RP, stanowi podstawową jednostkę samorządu terytorialnego. W myśl art. 1 ustawy o samorządzie gminnym jej mieszkańcy tworzą z mocy prawa wspólnotę samorządową, a ilekroć $\mathrm{w}$ przepisach ustawy jest mowa o gminie, należy przez to rozumieć wspólnotę samorządową oraz odpowiednie terytorium. Można więc wskazać, iż jest ona prawnie zorganizowanym terytorialnym związkiem osób, określonym w ustawie samorządowej mianem wspólnoty samorządowej, co podkreśla jej społeczny wymiar. Wspólnotę samorządową tworzą mieszkańcy gminy z mocy prawa. Zaspokajanie zbiorowych potrzeb owej wspólnoty należy do zadań własnych gminy. Do zakresu jej działania, zgodnie z art. 6 ustawy, należą wszystkie sprawy publiczne o znaczeniu lokalnym, niezastrzeżone ustawami na rzecz innych podmiotów, co oznacza swoiste domniemanie kompetencji, ustalone na rzecz tej jednostki samorządu terytorialnego, potwierdzające podstawowy charakter gminy wśród innych jednostek tego samorządu.

Gmina jako wspólnota samorządowa wykonuje zadania publiczne w imieniu własnym i na własną odpowiedzialność. Jest adresatem norm prawnych pozwalających na usytuowanie jej jako wyodrębnionego podmiotu prawa w strukturze organizacyjnej państwa. Został jej także zapewniony udział w sprawowaniu władzy publicznej, władzy wykonawczej, a ściślej rzecz ujmując — administracji publicznej. Spowodowało to dywersyfikację władzy wykonawczej. W miejsce istniejącej dotychczas jednolitej organizacyjnie administracji państwowej wydzielono administrację rządową i samorządową ${ }^{3}$.

Gmina została wyposażona w osobowość prawną, stając się podmiotem mienia komunalnego, niezbędnego dla realizacji przypisanych jej zadań. Przyznanie osobowości prawnej oraz zagwarantowanie sądowej ochrony samodzielności przez przepisy ustawy stało się wyrazem upodmiotowienia gminy. Artykuł 2 ust. 2 ustawy o samorządzie gminnym, określający jednoznacznie, iż gmina ma osobowość prawną, nie wskazał jednak, z jaką osobowością mamy do czynienia: prywatnoprawną, publicznoprawną czy też biwalentną osobowością prawną. Podział na osobowość publiczno- i prywatnoprawną jest niewątpliwie związany z powrotem do - nieobecnego przez długi czas w naszej rzeczywistości — dychotomicznego

3 Por. Prawo administracyjne, red. J. Boć, Wrocław 2010, s. 197-198. 
podziału prawa na prywatne i publiczne $e^{4}$. Tradycyjnie to właśnie te jednostki organizacyjne, które zostały powołane do wykonywania zadań administracji publicznej, z czym mamy do czynienia w wypadku wspólnot samorządowych, uznawane były w pierwszej kolejności za osoby prawne prawa publicznego.

Wspólnoty samorządowe, w tym oczywiście gmina, z mocy prawa zostały wyposażone w osobowość prawną, co oznacza, że mogą być podmiotami stosunków cywilnoprawnych. W takiej sytuacji zdolność prawna i zdolność do czynności prawnej w zakresie prawa cywilnego wynika $\mathrm{z}$ istoty osoby prawnej ${ }^{5}$.

Osoby prawne prawa publicznego tworzone są mocą ustawy lub aktu administracyjnego. Wśród kryteriów materialnych ich wyodrębniania bardzo mocno wskazuje się na: wykonywanie władzy publicznej, zobowiązanie do wypełniania zadań państwa, nadzór państwowy nad tym wykonawstwem oraz specyficzność celów i zadań realizowanych przez te osoby ${ }^{6}$. Majątek należący do tych osób, służący im do realizacji zadań publicznych, to majątek publiczny, wywodzący się z własności państwowej lub samorządowej, powracający do tych podmiotów po ustaniu bytu prawnego osób prawnych prawa publicznego ${ }^{7}$.

Gmina jako osoba prawna działa poprzez swoje organy, którymi - zgodnie z przepisami art. 11a ustawy — są rada gminy oraz wójt (burmistrz, prezydent miasta). Wójt jako organ wykonawczy gminy, najogólniej mówiąc, wykonuje uchwały organu stanowiącego gminy (rady gminy), gospodaruje mieniem komunalnym, zajmuje się budżetem oraz realizuje zlecone gminie zadania $\mathrm{z}$ zakresu administracji rządowej.

\section{Zadania publiczne gminy}

Zadania realizowane przez gminę są zadaniami publicznymi wykonywanymi przede wszystkim w interesie publicznym. Dzielone są na zadania własne oraz zlecone, wszakże zaspokajanie zbiorowych potrzeb wspólnoty należy do zadań własnych gminy. Wykonując zadania własne, lokalne sprawy publiczne ustawowo włączone do zakresu działania gminy, organ wykonawczy podlega wyłącznie radzie gminy, a wykonywane są one w imieniu i na własną odpowiedzialność gminy. W trakcie ich realizacji gmina korzysta z samodzielności chronionej na dro-

4 Por. S. Fundowicz, Dychotomiczny podziat prawa, „Samorząd Terytorialny” 2000, nr 1-2, s. 49.

5 Por. S. Dmowski, S. Rudnicki, Komentarz do kodeksu cywilnego. Ksiegga pierwsza. Część ogólna, Warszawa 2007, s. 127.

6 S. Fundowicz, Pojęcie osoby prawnej prawa publicznego, „Przegląd Sejmowy” 1999, nr 2 , s. 84 .

7 J. Frąckowiak, [w:] Zbigniew Banaszczyk et al., Prawo cywilne - część ogólna, red. M. Safjan, „System Prawa Prywatnego” 1, Warszawa 2012, s. 1171. 
dze sądowej. Z kolei wykonując zadania zlecone, które państwo powierza samorządowi ze względów pragmatycznych ${ }^{8}$, zazwyczaj w drodze normy ustawowej lub indywidualnych porozumień, organy wykonawcze gminy działają w imieniu administracji rządowej ${ }^{9}$ i niejako na jej rachunek. Ich wykonanie finansowane jest z przydzielonych na ten cel środków finansowych pochodzących z budżetu państwa, a ich realizacja zostaje poddana ściślejszemu nadzorowi niż w wypadku realizacji zadań własnych. Należy tu jednocześnie wskazać, iż podział zadań na własne oraz zlecone ma podstawy konstytucyjne, zawarte w art. 166 ustawy zasadniczej.

Zadania publiczne obejmują zmienną liczebnie i przedmiotowo pulę różnorodnych świadczeń podmiotów władzy publicznej na rzecz obywateli. Do tradycyjnych celów władzy, determinujących przedmiot zadań publicznych, w doktrynie zalicza się: zapewnienie stabilizacji oraz gospodarczy i społeczny rozwój, w tym dobrobyt obywateli i zachowanie wartości konstytucyjnych ${ }^{10}$. Najogólniej mówiąc, zadania publiczne są określane jako te, które służą zaspokojeniu zbiorowych potrzeb społecznych ${ }^{11}$, w tym indywidualnych potrzeb człowieka, wynikających z jego rozwoju życiowego, a także ze współżycia ludzi w społecznościach. To właśnie w dużej mierze decyduje o tym, że zadania te mają charakter niesłychanie dynamiczny ${ }^{12}$, a co za tym idzie - określenie celu zadań publicznych jest zmienne w czasie i przestrzeni, zależy od kontekstu prawnego, politycznego, społecznego, przyjmowanego w danym czasie i miejscu. W konsekwencji oznacza to, że nie można jednoznacznie ustalić zakresu i przedmiotu tych zadań raz na zawsze.

Ten gwałtowny wzrost roszczeń obywateli względem państwa, a w szczególności wspólnot samorządowych, spowodował pewne perturbacje w działaniach administracji publicznej. Jej stopień zorganizowania i możliwości materialne niestety nie pozwalają współcześnie na realizację wszystkich pokładanych w niej oczekiwań. Administracja, także samorządowa, stara się, o ile jest to możliwe, rezygnować z samodzielnej realizacji części zadań, które nie wydają się dzisiaj tak istotne ze społecznego punktu widzenia, jak kiedyś. W szczególności zadania socjalne ograniczane są z powodu braku wystarczających środków na ich realizację. Niekiedy wyjściem pozwalającym na pokonanie tych trudności jest realizacja tych zadań w ramach możliwości tworzonych przez partnerstwo publiczno-prywatne ${ }^{13}$.

${ }^{8}$ Por. M. Stahl, Samorząd terytorialny a państwo, „Studia Prawno-Ekonomiczne” 1992, z. 46, s. 53 .

9 Zob. uzasadnienie do orzeczenia TK z dnia 21 lutego 1995 r., sygn. U 2/94.

10 Szerzej zob. Z. Ziembiński, Wartości konstytucyjne, Warszawa 1993.

11 Por. S. Kasznica, Polskie prawo administracyjne, Poznań 1947, s. 7 n.

12 Por. S. Fundowicz, Dynamiczne rozumienie zadania publicznego, [w:] Między tradycja a przyszłościa w nauce prawa administracyjnego. Księga pamiątkowa poświęcona profesorowi Janowi Bociowi, red. J. Supernat, Wrocław 2009, s. 165.

13 Ustawa z dnia 19 grudnia 2008 r. o partnerstwie publiczno-prywatnym (tekst jedn. Dz.U. z 2015 r. poz. 696). 
Motywy prywatyzacji realizacji zadań publicznych mogą wynikać z interesów ekonomicznych (ograniczoności środków publicznych, niewystarczających na prawidłowe wykonanie tak wielkiej liczby zadań), co powoduje niebezpieczeństwo ich nadmiernej komercjalizacji, co z kolei może wywoływać niezadowolenie społeczne. W demokratycznym państwie prawnym nie powinno być miejsca na traktowanie zadań publicznych jako sfery płatnych usług publicznych. Ponadto może to oznaczać „wyjęcie” danej dziedziny z prawa administracyjnego i poszerzenie się obszarów prawa leżących pomiędzy prawem administracyjnym a prawem cywilnym, co powoduje rozmycie ostrości podziałów pomiędzy tymi gałęziami prawa. Nie bez znaczenia są tu także pewne pojawiające się przeszkody natury prawnej. $\mathrm{W}$ naszym porządku prawnym brakuje bowiem jednoznacznie wykształconych, wprowadzonych ustawowo, form działania administracji, za pomocą których taka prywatyzacja mogłaby występować jednolicie i bezpiecznie, czyli przy zastosowaniu jasnych reguł i sposobów kontroli ${ }^{14}$.

\section{Bezpieczeństwo jako zadania publiczne}

Ochrona bezpieczeństwa i porządku publicznego jest jednym z najstarszych zadań publicznych realizowanym przez związki publicznoprawne (przede wszystkim państwo), powiązanym ściśle z powstawaniem władzy publicznej ${ }^{15}$. Potrzeba zapewnienia porządku i bezpieczeństwa zajmowała i wciąż zajmuje podstawowe miejsce w hierarchii potrzeb i dóbr człowieka. Bezpieczeństwo publiczne, a w zasadzie poczucie bezpieczeństwa, oraz porządek to wartości, które państwo powinno zapewnić i chronić. Współcześnie ich ochrona stanowi jedno z fundamentalnych zadań administracji każdego państwa ${ }^{16}$.

W przypadku gminy jest ona jednym z jej podstawowych zadań, którego realizacja powinna zaspokajać istotne potrzeby wspólnoty samorządowej w tym zakresie. Zgodnie z art. 7 ust. 1 ustawy o samorządzie gminnym taką potrzebą wspólnoty, wyrażającą się zadaniem gminy, są również sprawy porządku publicznego i bezpieczeństwa obywateli oraz ochrony przeciwpożarowej i przeciwpowodziowej, w tym wyposażenia i utrzymania gminnego magazynu przeciwpowodziowego.

Zapewnienie porządku i bezpieczeństwa publicznego jest niezmiernie ważne dla działającego w interesie publicznym państwa, choć nie ulega wątpliwości, że dokonywane jest także w interesie jednostki — jednostki, która przede wszystkim

14 Por. J. Zimmermann, Prawo administracyjne, Kraków 2005, s. 145.

15 Por. M. Mączyński, Powiat w systemie ochrony bezpieczeństwa i porządku publicznego, „Przegląd Prawa Publicznego” 2007, nr 6, s. 71.

16 Por. Z. Duniewska, Prawo ochrony bezpieczeństwa i porzadku publicznego, [w:] Materialne prawo administracyjne. Pojęcia, instytucje, zasady, red. M. Stahl, Warszawa 2002, s. 331. 
jest beneficjentem utrzymywania w życiu społecznym tych stanów i dlatego też powinna przyczyniać się do ich utrzymania, gdyż odgrywają one zasadniczą rolę w zapewnieniu ochrony jej podstawowych dóbr, czyli życia, zdrowia i mienia. Zapewnienie tych stanów jest praktycznie niemożliwe bez udziału w nim samych jednostek oraz instytucjonalnych form ich organizowania się.

W nauce zwraca się uwagę na trudności, jakie są związane ze zdefiniowaniem pojęć „,bezpieczeństwo publiczne” i „porządek publiczny”. Wskazywano, iż ich definicje, o ile zostaną ustalone, mogą być ,tylko dość ogólne"17. W rozumieniu słownikowym bezpieczeństwo to tyle, co „stan niezagrożenia, spokoju, pewności”" Odnosi się ono do wszystkich sfer życia człowieka i zawsze łączone jest z zagrożeniem, czyli niebezpieczeństwem ${ }^{19}$. Bezpieczeństwo wewnętrzne z kolei łączy się z pewną cechą szczególną, jaka jest lokalność występującego zagrożenia ${ }^{20}$.

Wskazywano, iż

znaczeniowo pod wyrazami bezpieczeństwo, spokój i porządek publiczny ogólnie rozumiemy pewne dodatnie stany panujące w organizacji społecznej, których zachowanie gwarantuje uniknięcie określonych szkód tak przez całość organizacji, jak i przez poszczególnych jej członków ${ }^{21}$.

\section{Pojęciem}

bezpieczeństwa publicznego obejmuje się ogół warunków i instytucji chroniących życie, zdrowie i mienie obywateli oraz ustrój państwowy i majątek ogólnonarodowy. Porządek publiczny zaś można byłoby określić jako stan charakteryzujący się poszanowaniem nakazów i zakazów prawnych oraz zasad dotyczących w szczególności zachowania się w miejscach publicznych ${ }^{22}$.

Ochrona przeciwpożarowa to wszakże realizacja przedsięwzięć mających na celu ochronę życia, zdrowia, mienia lub środowiska przed pożarem, klęską żywiołową lub innym miejscowym zagrożeniem ${ }^{23}$, zaś ochrona przed powodzią ma na celu, w szczególności, ograniczenie potencjalnych negatywnych skutków powodzi dla życia i zdrowia ludzi, środowiska, dziedzictwa kulturowego oraz działalności gospodarczej ${ }^{24}$.

Przeciwdziałanie zagrożeniom porządku i bezpieczeństwa publicznego wymaga współdziałania wielu podmiotów, możliwości skutecznego łączenia ich sił dla odparcia tego, co zagraża podstawowym dobrom człowieka, takim jak ży-

17 J. Starościak, Prawo administracyjne, Warszawa 1977, s. 541.

18 Por. Stownik języka polskiego, red. M. Szymczak, Warszawa 1978, s. 147.

19 Por. S. Pieprzny, Ochrona bezpieczeństwa i porzadku publicznego w prawie administracyjnym, Rzeszów 2007, s. 13.

20 Por. J. Boć, O bezpieczeństwie wewnętrznym, [w:] Bezpieczeństwo wewnętrzne $w$ działaniach terenowej administracji publicznej, red. A. Chajbowicz, T. Kocowski, Wrocław 2009, s. 24.

21 Por. W. Kawka, Policja w ujęciu historycznym i współczesnym, Wilno 1939, s. 49; S. Pieprzny, op. cit., s. 13-45.

22 Por. E. Smoktunowicz, Encyklopedia obywatela PRL. Status administracyjnoprawny, Warszawa 1987, s. 80.

23 Art. 1 ustawy o ochronie przeciwpożarowej.

24 Art. 88a Ustawy z dnia 18 lipca 2001 r. — Prawo wodne (tekst jedn. Dz.U. z 2017 r. poz. 1121) 
cie, zdrowie i mienie. W gminie na poziomie lokalnym zadania w sferze ochrony przeciwpożarowej i przeciwpowodziowej, obok tej podstawowej jednostki samorządu, realizują Ochotnicze Straże Pożarne, które jako stowarzyszenia mają status jednostek ochrony przeciwpożarowej.

Swoistą koordynację działań podejmowanych na terenie gminy przez różne jednostki mające na celu zagwarantowanie bezpieczeństwa przewiduje Ustawa z dnia 26 kwietnia 2007 r. o zarządzaniu kryzysowym ${ }^{25}$. Jej przepisy (art. 19) zakładają powołanie gminnego zespołu zarządzania kryzysowego jako organu pomocniczego wójta w celu zapewnienia wykonywania zadań zarządzania kryzysowego. W skład takiego zespołu wchodzą przedstawiciele społecznych organizacji ratowniczych ${ }^{26}$. Trudno wszakże nie zgodzić się z poglądem, iż jedynym podmiotem mogącym w miarę profesjonalnie uczestniczyć $\mathrm{w}$ zarządzaniu kryzysowym w gminie jest miejscowa Ochotnicza Straż Pożarna ${ }^{27}$.

\section{Ochotnicza Straż Pożarna jako stowarzyszenie}

Jedną z jednostek społecznych organizacji ratowniczych jest Ochotnicza Straż Pożarna, która równocześnie stanowi formę aktywności obywateli realizujących swe konstytucyjne prawo do zrzeszania się. Artykuł 58 Konstytucji RP orzeka, iż każdemu zapewnia się wolność zrzeszania się. Formą organizacyjno-prawną pozwalającą na skuteczną realizację tego prawa obywatelskiego jest właśnie stowarzyszenie. Sytuację prawną stowarzyszeń regulują przepisy Ustawy z dnia 7 kwietnia 1989 r. - Prawo o stowarzyszeniach ${ }^{28}$. Dokument ten normuje działalność stowarzyszeń, czyli dobrowolnych, samorządnych, trwałych zrzeszeń o celach niezarobkowych, pozwalających na reprezentowanie zbiorowych interesów swoich członków.

Stowarzyszenie jest organizacją samodzielnie określającą swoje cele, programy działania i struktury organizacyjne oraz uchwalającą akty wewnętrzne dotyczące jego działalności. Swą działalność opiera na społecznej pracy swoich członków, co nie wyklucza możliwości zatrudniania pracowników, w tym swoich członków, do prowadzenia jego spraw. Podlega ono obowiązkowi wpisu do Krajowego Rejestru Sądowego. Wniosek w tej sprawie podpisują wszyscy członkowie zarządu.

25 Dz.U. z 2017 r. poz. 209.

26 Szerzej na ten temat zob. J. Filaber, Ochrona bezpieczeństwa publicznego w gminie, Warszawa 2016, s. 90-106.

27 Por. A. Pakuła, Rola terenowej administracji publicznej w zapobieganiu sytuacjom kryzysowym, [w:] Powszechna ochrona ludności w stanach nadzwyczajnych $w$ zadaniach terenowej administracji publicznej, red. T. Kocowski, M. Błażewski, M. Raduła, Wrocław 2017, s. 134.

28 Dz.U. z 2017 r. poz. 210. 
Ochotnicza Straż Pożarna po wpisie uzyskuje osobowość prawną i może rozpocząć swą działalność statutową.

Podstawowym dokumentem wewnętrznym stowarzyszenia jest niewątpliwie jego statut. Zgodnie z art. 9 ustawy osoby, w liczbie co najmniej 7, zamierzające założyć stowarzyszenie, uchwalają statut stowarzyszenia, który określa w szczególności:

1) nazwę stowarzyszenia, odróżniającą je od innych stowarzyszeń, organizacji i instytucji;

2) teren działania i siedzibę stowarzyszenia;

3) cele i sposoby ich realizacji;

4) sposób nabywania i utraty członkostwa, przyczyny utraty członkostwa oraz prawa i obowiązki członków;

5) władze stowarzyszenia, tryb dokonywania ich wyboru, uzupełniania składu oraz ich kompetencje;

6) możliwość otrzymywania przez członków zarządu wynagrodzenia za czynności wykonywane w związku z pełnioną funkcją;

7) sposób reprezentowania stowarzyszenia, w szczególności sposób zaciągania zobowiązań majątkowych, a także warunki ważności uchwał władz stowarzyszenia;

8) sposób uzyskiwania środków finansowych oraz ustanawiania składek członkowskich.

Ochotnicza Straż Pożarna jako stowarzyszenie mające osobowość prawną działa przez swoje organy. Najwyższą władzą stowarzyszenia jest walne zebranie członków. W sprawach, w których statut nie określa właściwości władz stowarzyszenia, podejmowanie uchwał należy do walnego zebrania członków. Stowarzyszenie jest zobowiązane posiadać zarząd oraz organ kontroli wewnętrznej. Zarząd nadzoruje działalność stowarzyszenia i reprezentuje je, a szczegółowe kompetencje zarządu lub poszczególnych jego członków w tej dziedzinie wynikają z postanowień statutu.

Stowarzyszenie jako osoba prawna posiada swój majątek, który powstaje ze składek członkowskich, darowizn, spadków, zapisów, dochodów z własnej działalności, dochodów z majątku stowarzyszenia oraz z ofiarności publicznej. Stowarzyszenie, z zachowaniem obowiązujących przepisów, może przyjmować darowizny, spadki i zapisy oraz korzystać z ofiarności publicznej. Może też otrzymywać dotacje według zasad określonych we właściwych przepisach.

Ochotnicza Straż Pożarna jest o tyle nietypowym stowarzyszeniem, że można zakwalifikować ją do społecznych organizacji ratowniczych. Na jej status wpływa również fakt, iż jest ono równocześnie jednostką organizacyjną ochrony przeciwpożarowej. 


\section{Ochotnicza Straż Pożarna jako jednostka organizacyjna ochrony przeciwpożarowej}

Ochotnicza Straż Pożarna jest jednostką organizacyjną ochrony przeciwpożarowej i w tym zakresie jej sytuację regulują przepisy ustawy o ochronie przeciwpożarowej. Ochrona przeciwpożarowa, zgodnie z art. 1 ustawy, polega na realizacji przedsięwzięć mających na celu ochronę życia, zdrowia, mienia albo środowiska przed pożarem, klęską żywiołową lub innym miejscowym zagrożeniem poprzez: zapobieganie powstawaniu i rozprzestrzenianiu się pożaru, klęski żywiołowej lub innego miejscowego zagrożenia; zapewnienie sił i środków do zwalczania pożaru, klęski żywiołowej lub innego miejscowego zagrożenia; oraz prowadzenie działań ratowniczych.

W tej dziedzinie przewidziana jest podstawowa aktywność tego typu jednostek, będących stowarzyszeniami i posiadających osobowość prawną. Celami tego typu stowarzyszenia są:

1) prowadzenie działalności mającej na celu zapobieganie pożarom oraz współdziałanie w tym zakresie z Państwową Strażą Pożarną, organami samorządowymi i innymi podmiotami;

2) udział w akcjach ratowniczych przeprowadzanych w czasie pożarów, zagrożeń ekologicznych związanych z ochroną środowiska oraz innych klęsk i zdarzeń;

3) informowanie ludności o istniejących zagrożeniach pożarowych i ekologicznych oraz sposobach ochrony przed nimi;

4) rozwijanie wśród członków Ochotniczej Straży Pożarnej kultury fizycznej i uprawiania sportu oraz prowadzenia działalności kulturalno-oświatowej i rozrywkowej;

5) wykonywanie innych zadań wynikających z przepisów o ochronie przeciwpożarowej oraz niniejszego statutu;

6) działania na rzecz ochrony środowiska;

7) uczestniczenie i reprezentowanie OSP w organach samorządowych i przedstawicielskich.

Realizacjom tych celów podporządkowana jest struktura organizacyjna stowarzyszenia, a przede wszystkim powołanie w jej ramach jednostki operacyjno-technicznej, na czele której stoi naczelnik, będący równocześnie wiceprezesem zarządu stowarzyszenia — Ochotniczej Straży Pożarnej. Tworzenie jednostek operacyjno-technicznych Ochotniczej Straży Pożarnej należy do kompetencji zarządu.

Jednostką operacyjno-techniczną jednoosobowo kieruje naczelnik, do kompetencji którego należy m.in. wnioskowanie do zarządu OSP o wyznaczenie członków OSP do wykonania zadań operacyjno-technicznych, organizowanie i prowadzenie podstawowego szkolenia pożarniczego członków OSP, drużyn młodzieżowych i kobiecych OSP, kierowanie przeciwpożarową działalnością za- 
pobiegawczą oraz w przeprowadzanych akcjach ratowniczo-gaśniczych, dysponowanie sprzętem i urządzeniami pożarniczymi OSP, a także nadzorowanie ich prawidłowej eksploatacji i konserwacji.

Zgodnie z przepisami ustawy o ochronie przeciwpożarowej Ochotnicza Straż Pożarna jest jednostką umundurowaną, wyposażoną w specjalistyczny sprzęt, przeznaczoną w szczególności do walki z pożarami, klęskami żywiołowymi lub innymi miejscowymi zagrożeniami. Koszty wyposażenia, utrzymania, wyszkolenia i zapewnienia gotowości bojowej Ochotniczej Straży Pożarnej ponosi gmina. Ma ona również obowiązek bezpłatnego umundurowania członków OSP; ubezpieczenia ich i młodzieżowej drużyny pożarniczej w instytucji ubezpieczeniowej oraz ponoszenia kosztów ich okresowych badań lekarskich.

Strażacy jednostek ochrony przeciwpożarowej powinni wykazywać zdolność fizyczną i psychiczną do pracy w tych jednostkach. Oceny zdolności fizycznej i psychicznej strażaka do pracy dokonuje lekarz służby medycyny pracy. Bezpośredni udział w działaniach ratowniczych mogą brać członkowie Ochotniczych Straży Pożarnych, którzy ukończyli 18, ale nie przekroczyli 65 lat, posiadający aktualne badania lekarskie dopuszczające do udziału w działaniach ratowniczych oraz którzy odbyli szkolenie pożarnicze.

\section{Gmina oraz Ochotnicze Straże Pożarne w krajowym systemie ratowniczo-gaśniczym}

Przepisy art. 14 ustawy o ochronie przeciwpożarowej stanowią, iż utworzony krajowy system ratowniczo-gaśniczy ma na celu ochronę życia, zdrowia, mienia lub środowiska poprzez: walkę z pożarami lub innymi klęskami żywiołowymi; ratownictwo techniczne; ratownictwo chemiczne; ratownictwo ekologiczne; ratownictwo medyczne. Stanowi on integralną część organizacji bezpieczeństwa wewnętrznego państwa, obejmującą — w celu ratowania życia, zdrowia, mienia lub środowiska - prognozowanie, rozpoznawanie i zwalczanie pożarów, klęsk żywiołowych lub innych miejscowych zagrożeń.

Ma on zapewnić prawidłowe działanie sił i środków systemu w wypadku wystąpienia sytuacji nadzwyczajnych i doprowadzić do tego, by profesjonalne i wyspecjalizowane jednostki podjęły działania i udzieliły jak najszybszej pomocy, doprowadzając w przypadku wystąpienia niekorzystnego zjawiska do zminimalizowania jego negatywnych, indywidualnych, społecznych lub środowiskowych skutków. Ochotnicze Straże Pożarne — z racji prezentowanej fachowości — stają się predestynowane do uzyskania statusu jednostek tego systemu.

Włączenie Ochotniczej Straży Pożarnej do krajowego systemu ratowniczo-gaśniczego poprzedzone jest zawarciem porozumienia między właściwym miej- 
scowo komendantem powiatowym (miejskim) Państwowej Straży Pożarnej, tą jednostką a wójtem gminy. Porozumienie, które zawierane jest na czas określony, powinno określać m.in.:

1) deklarowaną gotowość operacyjną, w tym siły i środki jednostki przewidziane do wykorzystania w systemie;

2) zadania ratownicze przewidziane dla jednostki w ramach systemu;

3) wymaganą liczbę i wymagany poziom wyszkolenia ratowników w jednostce;

4) sposób utrzymania stanu gotowości jednostki do działań ratowniczych, w szczególności w zakresie:

a) sprawności technicznej samochodów pożarniczych i ich wyposażenia,

b) przygotowania ratowników do działań,

c) przebiegu alarmowania,

d) sposobu przekazywania informacji dotyczącej aktualnej gotowości operacyjnej lub jej czasowego obniżenia ${ }^{29}$.

Wójt koordynuje funkcjonowanie krajowego systemu ratowniczo-gaśniczego na obszarze gminy w zakresie ustalonym przez wojewodę. Zadanie to może być wykonywane przez komendanta gminnego ochrony przeciwpożarowej, jeżeli taki komendant został zatrudniony przez wójta, albo przez komendanta gminnego związku Ochotniczych Straży Pożarnych.

\section{Zakończenie}

Ograniczone ramy niniejszego artykułu pozwalają jedynie zasygnalizować sprawy związane z realizacją zadań gminy z zakresu ochrony przeciwpożarowej. Dodatkowo określony wpływ na wykonywanie części tych zadań ma powołana instytucja krajowego systemu ratowniczo-gaśniczego. Nie ulega wątpliwości, iż na szczeblu gminnym dużą rolę w realizacji zadań systemu, którego koordynatorem jest wójt, odgrywają - mające status stowarzyszeń - Ochotnicze Straże Pożarne. Powołanie krajowego system ratowniczo-gaśniczego spowodowało zmianę tradycyjnego modelu tych stosunków. Ochotnicze Straże Pożarne także stały się elementem powstałego systemu. Nowa sytuacja w tej dziedzinie wymaga jednak szczegółowego i kompleksowego zbadania.

29 Zob. § 3 Rozporządzenia Ministra Spraw Wewnętrznych z dnia 15 września 2014 r. w sprawie zakresu, szczegółowych warunków i trybu włączania jednostek ochrony przeciwpożarowej do krajowego systemu ratowniczo-gaśniczego (Dz.U. z 2014 r. poz. 1317). 


\section{Municipality and volunteer fire brigades in executing fire protection tasks}

\section{Summary}

One of the public tasks of the municipality are matters of public order and security of citizens and fire protection. In the area of the municipality they were made by volunteer fire brigades assisted in cash by the municipality. Changes in such a system were caused by the emergence of a national rescue and firefighting system, hence the need to investigate the current model of these relations.

Keywords: commune, municipal tasks, volunteer fire brigade, national rescue and firefighting system. 